\title{
Algunas consideraciones en torno a la concesión recaudación y gasto del pedido regio en Sevilla y su tierra en $1454^{1}$
}

\author{
Some considerations about the concession, collection and \\ expenditure of the royal "pedido" in Seville and its lands in 1454
}

\author{
José Manuel Triano MiLÁN \\ Universidad de Málaga \\ j.m.triano@hotmail.com \\ Julieta RoDRÍGUEZ SARRIA \\ Universidad de Málaga \\ julietarsarria@hotmail.com
}

Recibido: 01/09/2014

Aceptado: 31/10/2014

\section{RESUMEN}

El presente artículo profundiza en el estudio del pedido regio a través del análisis de su funcionamiento en Sevilla y su tierra en 1454. Mediante el examen del proceso de concesión, recaudación y gasto de este subsidio podremos observar aspectos de interés, como el papel que desempeñó en las relaciones de poder entre monarquía y Cortes o las dificultades que fueron surgiendo en el proceso de cobro de este importante recurso.

Palabras clave: Castilla, Cortes, Pedido regio, Sevilla, fiscalidad.

\begin{abstract}
This article examines the study of the royal pedido analysing the particular case of its application in the city of Seville and its lands in 1454. Through the examination of the concession process, the collection and spending of this tribute we can see aspects such as its role in the power relations between Monarchy and Parliament or the difficulties in the collection process.
\end{abstract}

Key words: Castile, Parliament, Royal "pedido", Seville, Taxation.

Sumario: 1. Introducción. 2. Concesión del pedido de 1454. 3. Un año conflictivo en el proceso de recaudación. 4. El gasto. 5. Conclusiones.

\footnotetext{
${ }^{1}$ Este artículo se inscribe en el marco de una beca FPI del MICINN asociada al proyecto de investigación "Fiscalidad y sociedad en la Corona de Castilla al sur del Tajo" (HAR 2011-26218) integrado en la red temática de investigación Arca Comunis (arcacomunis.uma.es). Abreviaturas utilizadas AGS= Archivo General de Simancas; AMS= Archivo Municipal de Sevilla; EMR=Escribanía Mayor de Rentas; Pap. May.= Papeles del Mayordomazgo. 


\section{INTRODUCCIÓN}

El pedido regio -concepto que junto a las monedas constituyó el denominado servicio de Cortes- se convirtió, a lo largo del siglo XV, en uno de los pilares fundamentales de la Hacienda castellana. Creado, o más bien recuperado ${ }^{2}$, en 1406 como una figura fiscal complementaria a las monedas, pronto superó en importancia a éstas, transformándose en el ingreso extraordinario más importante de la Corona ${ }^{3}$. Pese a su relevancia ${ }^{4}$ nuestro desconocimiento sobre el mismo ha sido casi absoluto hasta fechas relativamente recientes. Poco sabíamos sobre el pedido, aparte del hecho de que era una concesión de las Cortes al monarca que, a diferencia de las monedas, se caracterizaba porque no era arrendada sino recaudada por los concejos. Por suerte, en los últimos años el vacío historiográfico existente ha venido a ser ocupado por una serie de trabajos que nos han mostrado cómo se articulaban las relaciones entre los órganos centrales de la Hacienda y los municipios, la forma en la que éstos últimos ponían en funcionamiento el sistema de recaudación y cómo se llevaba éste a cabo. Éstos y otros aspectos de interés han sido objeto de estudio en algunas síntesis generales $^{5} \mathrm{y}$ en diversos trabajos que han venido a mostrarnos como funcionaba el pedido a nivel municipal ${ }^{6}$. En este sentido, los análisis centrados en la ciudad de Sevilla han resultado especialmente clarificadores, gracias a la valiosísima información que en torno a este aspecto se ha conservado en su Archivo Municipal. Allí se encuentran los denominados libros de pedido ${ }^{7}$, en los que se registraban buena parte de la documentación generada por la recaudación de este subsidio en la ciudad hispalense y su alfoz. Estos documentos proporcionan abundantes noticias y datos de carácter serial, algo que no parece darse en otras partes de la Corona ${ }^{8}$.

No obstante, pese a estos avances, resulta evidente que aún es mucho lo que queda por hacer. Hay algunos aspectos sobre los que apenas se ha incidido aún y somos conscientes de que la imagen que se ha transmitido de este subsidio ha de ser matizada. En este sentido, creemos que es importante romper con la visión, un tanto

${ }^{2}$ Sobre los precedentes del pedido regio pueden consultarse los estudios de SÁnchez Albornoz, "Notas para el estudio del Petitum", pp. 383-418 y LADERo Quesada, Fiscalidad y poder real, pp. 51-52.

${ }^{3}$ Rodríguez SARRIA, “¿Cobrar para el rey?”, p. 80.

${ }^{4}$ Hemos de recordar que, tal y como ha señalado el profesor Carretero en diversas ocasiones, los servicios de Cortes no son impuesto sino un subsidio o ayuda, producto de una concesión de las Cortes al monarca Carretero Zamora, Cortes, Monarquía, ciudades, p. 61.

${ }^{5}$ Ladero Quesada, La Hacienda Real de Castilla y Romero Martínez, Fisco y recaudación, Contamos, así mismo, con estudios para grandes regiones de la Corona como los de Olivera SERRAno, "El pedido de 1455 en el reino de Galicia", pp. 363-374 y Rubio Martínez, "Los ingresos extraordinarios en el reino de Galicia", pp. 229-271.

${ }^{6}$ Entre ellos destacan los de GonzÁlez Arce, "Los precedentes de la fiscalidad extraordinaria de la Monarquía hispana"; Olivera Serrano, "Pedidos y monedas en Valladolid y su infantado"; Romero Romero, Sevilla y los pedidos de Cortes y RodríGUEZ SARRIA, “¿Cobrar para el rey?”

${ }^{7}$ Disponemos de los libros de pedido de 1406, 1407, 1408, 1411, 1430, 1432, 1435, 1436, 1438, 1440, 1442, 1443, 1445, 1447, 1449, 1452, 1454, 1455, 1459, 1460-61 y 1469-70. Aunque algunos sólo se conservan de manera muy fragmentaria. A ello hay que unir la presencia de documentos vinculados a los pedidos recaudados en 1463 y 1441, cuyos libros de pedido no se conservan. Para algunas interesantes consideraciones en torno a esta importante documentación véase Romero Romero, Sevilla y los pedidos de Cortes, p. 12.

${ }^{8}$ Ibid. 
estática, que se ha dado del mismo. Preocupados por comprender las líneas generales del funcionamiento del pedido, los diversos estudios centrados en este ingreso han incidido poco sobre las importantes transformaciones que éste experimentó a lo largo de su existencia. Ello ha impedido que algunos asuntos íntimamente relacionados con dicha evolución, como su vinculación a la conflictiva relación que mantuvieron entre sí las Cortes y la Monarquía a lo largo de buena parte del siglo $\mathrm{XV}^{9} \mathrm{o}$ el progresivo deterioro del proceso de recaudación, hayan recibido la atención que merecen.

Nuestro objetivo aquí será, precisamente, arrojar luz sobre estos aspectos a través del estudio del proceso de concesión, recaudación y cobro del pedido del año 1454. Un momento de especial interés, ya que el fallecimiento de Juan II este año marca el final de un período en la historia de esta ayuda y deja entrever los inicios de una nueva etapa, caracterizada por las reformas introducidas por Enrique IV.

\section{CONCESIÓN DEL PEDIDO DE 1454}

Las particulares condiciones por las que atravesó Castilla en los últimos años del reinado de Juan II afectaron a la relación entre las Cortes y el monarca, algo que no podía dejar de reflejarse uno de los aspectos que en este período condicionaba la comunicación entre estas dos instituciones: la concesión del pedido y las monedas ${ }^{10}$. La caída de don Álvaro de Luna, condestable de Castilla y hombre de confianza de Juan II hasta ese momento, suponía una radical transformación del panorama político castellano ${ }^{11}$. Los procuradores de Cortes eran conscientes de que este acontecimiento podía alterar de manera irreparable el delicado equilibrio de poderes constituido en los últimos años y limitar, aún más, sus ya limitadas capacidades como órgano representativo ${ }^{12}$. Todo ello obligaba a actuar con cautela a las ciudades y mantener una actitud menos combativa de lo que había venido siendo habitual. Así lo podemos observar en el documento de otorgamiento del servicio de $1454^{13}$, redactado en abril de 1453 en Portillo, lugar en el que se encontraba preso el Condestable. En éste los representantes de las ciudades no sólo no incidieron en sus protestas sobre la mala situación de la Hacienda con su habitual vehemencia sino que, además, plantearon escasos "apuntamientos" o peticiones a cambio de la concesión del servicio.

Entre las pocas demandas que sí se atrevieron a formular destacan la de que las cantidades del servicio no fueran destinadas a gastos ordinarios y que se realizara

${ }^{9}$ En torno a las tensiones entre Cortes y monarquía a finales del reinado de Juan II consúltese Round, The greatest man uncrowned., pp. 51 y ss.

${ }^{10}$ Esta situación no es exclusivamente castellana sino que es común a las monarquías de Europa Occidental Carretero Zamora, "Fiscalidad extraordinaria y deuda", p. 11.

${ }^{11}$ Un completo análisis sobre la caída de don Álvaro de Luna puede consultarse el ya citado estudio de Round, The greatest man uncrowned.

${ }^{12}$ Como señaló el profesor Valdeón, las Cortes de Castilla mostraron una continuada decadencia, quedando lejos del protagonismo político que lograron mostrar en algunos momentos del siglo XIV. VALDEÓN BARUQue, "Las Cortes de Castilla", p. 293.

${ }^{13}$ El documento de otorgamiento fue publicado por Olivera Serrano, Las Cortes de Castilla y León, pp. 249 y ss. 
un libramiento sobre el total de la cantidad otorgada para pagarles sus salarios por el desempeño de su cargo. Así mismo, solicitaron que, junto a este dinero, también se les abonasen los retrasos que se les debían, ya que, pese a las promesas del rey, no habían recibido nada sobre la cantidad recaudada en el servicio de 1453. Pero el aspecto en el que los procuradores pusieron una mayor atención, y el que más nos interesa aquí, fue la solicitud para conseguir la confirmación de las prerrogativas obtenidas en $1445^{14}$. Ese año, tras la victoria obtenida en Olmedo sobre la Liga, Juan II había hecho realidad algunas de las antiguas aspiraciones de las Cortes. Entre éstas cabe destacar la capacidad que les fue concedida a los procuradores para nombrar a los recaudadores mayores del pedido y las monedas. A ello se unieron una serie de disposiciones orientadas a asegurar que los representantes de las ciudades cobraran sus prestaciones siempre a tiempo y por completo ${ }^{15}$, al percibir estas sumas directamente sobre las cantidades recaudadas por los agentes fiscales por ellos designados ${ }^{16}$. De esta manera, la Corona implicaba aún más a las ciudades en el proceso de recaudación y fomentaba el interés de éstas en que el funcionamiento del mismo fuese el correcto. Además, se aseguraba su apoyo en un momento en el que la situación política era aún bastante inestable. Las ciudades, por su parte, daban un paso importante hacia el que fue su principal objetivo durante el siglo XV: lograr el control sobre los servicios por ellas concedidos. Conscientes de que su única oportunidad para lograr un verdadero peso político pasaba por alcanzar esta capacidad, todos sus esfuerzos se concentraron en ello. En este sentido, lo conseguido en 1445 parecía un gran avance en esa dirección, pero pronto quedó demostrado que los procuradores se encontraban aún lejos de alcanzar su gran aspiración. Así lo muestra el hecho de que la última palabra sobre el aspecto verdaderamente determinante para controlar el servicio, decidir en que partidas se gastaba el dinero recaudado, siguiera perteneciendo al rey ${ }^{17}$. Además, pese a que estos privilegios otorgados en las Cortes de Olmedo fueron confirmados en numerosas ocasiones, las interferencias de Juan II en el proceso de recaudación fueron constantes a lo largo de estos años ${ }^{18}$. Aunque el monarca necesitaba a las ciudades no estaba dispuesto a ceder por completo el control de la recaudación de una de sus principales bases financieras, aunque supusiera atentar contra los derechos por él concedidos. Ello nos permite entender el interés de los procuradores en que se confirmaran sus privilegios y la velada lucha que iban a mantener con la monarquía por este asunto.

Volviendo a 1454, vemos como el rey, interesado en legitimar sus acciones contra Álvaro de Luna y lograr unos subsidios que le eran muy necesarios, acabará aceptando y confirmando todas estas peticiones de las Cortes. Juan II contaba con grandes deudas con algunas de las principales familias nobiliarias de la Corona ${ }^{19}$

${ }^{14}$ La confirmación de estas prerrogativas se encuentra en Olivera Serrano, Las Cortes de Castilla y León, pp. 240 y ss.

15 Romero Martínez, Fisco y recaudación, p. 21.

${ }^{16}$ Así podemos verlo en el documento de la concesión de estas capacidades por parte de Juan II en 1445. Olivera Serrano, Las Cortes de Castilla y León, pp. 183 y ss.

17 Ibid.

18 Ibid.

${ }^{19}$ A los diversos préstamos concedidos por algunos de los principales linajes nobiliarios de la Corona hay que unir la gran cantidad de juros y mantenimientos con respecto a éstos a los que la Hacienda real tenía que 
que necesitaban ser satisfechas. Además, la empresa militar en Navarra en la que estaba envuelto, así como otras operaciones militares de menor envergadura en Aragón y en algunos territorios de la Corona de Castilla, seguía demandando importantes sumas de dinero ${ }^{20}$. Todo ello nos permite entender que cediese ante las pretensiones de las ciudades. Pero esta decisión seguramente, no era más que una medida temporal, hasta que la situación se estabilizara. La pregunta era si una vez ocurrido esto el monarca seguiría manteniendo las medidas adoptadas en 1445 o pondría punto y final a este asunto de una vez por todas. Su fallecimiento en julio de ese mismo año de 1454 nos impide saber cuál era el destino que tenía planeado para las Cortes.

Sea como fuere, los privilegios alcanzados por los procuradores quedaron salvaguardados temporalmente mientras que, en contraprestación, concedían $35 \mathrm{mi}$ llones de maravedís para hacer frente a las necesidades financieras de Juan $\mathrm{II}^{21}$. La cifra otorgada podría parecer poco elevada si la comparamos con otros servicios, pero en modo alguno lo era, ya que se venía a sumar a una cantidad similar concedida el año anterior. En total, unos 70 millones de maravedíes en apenas dos años, una cifra verdaderamente importante ${ }^{22}$. Más aún en unos momentos en los que la situación hacendística de la Corona no atravesaba por sus mejores momentos. Y es que la Real Hacienda se mostraba cada vez más incapaz de hacer frente a sus crecientes gastos únicamente con sus ingresos ordinarios ${ }^{23}$. Es por ello que la solicitud de dinero a las Cortes se convirtió en un recurso cada vez más frecuente. De hecho, desde inicios de la década de los cincuenta, se habían demandado servicios de forma anual ${ }^{24}$. Las ayudas de esta institución se habían convertido, en las afortunadas palabras del profesor Olivera, en un "sistema ordinario de proporcionar ingresos extraordinarios a la Corte" ${ }^{25}$.

Para hacer efectivo el ingreso de los 35 millones de maravedís concedidos este año se estableció una normativa clara acerca de los plazos en la que debía ser recaudado el dinero, como venía siendo habitual:

hacer frente y que no dejaban de crecer. SuÁrez Fernández, Nobleza y Monarquía, pp. 269-270.

20 Ibid.

${ }^{21}$ Carta del pedido de 1454. AMS, Pap. May., Rollo 266, Caja 55, Pedido de 1454.

22 Para una evolución de las sumas concedidas en el servicio de Cortes véase LADERo QuesadA, La Hacienda Real de Castilla, p. 220 y Rodríguez SARria, “Cobrar para el rey?”, p. 96.

23 Para hacerse una idea de los importantes gastos ordinarios a los que hubo de hacer frente la Monarquía consúltese SuÁrez FernáNDEZ, "Un libro de asientos de Juan II", pp. 322-368.

${ }^{24}$ Ladero Quesada, La Hacienda Real de Castilla, p. 220.

25 Olivera Serrano, Las Cortes de Castilla y León, p. 18. 
Tabla1. Plazos de pago del servicio de $1454^{26}$

\begin{tabular}{|c|c|c|}
\hline Plazo & Concepto & Maravedís toda la Corona \\
\hline $\begin{array}{l}\text { Durante los } 40 \text { días siguientes a } \\
\text { partir del día } 1 \text { de enero (dos pagos } \\
\text { en plazos de } 20 \text { días cada uno) }\end{array}$ & 8 monedas y un pedido & 20.000 .000 \\
\hline $\begin{array}{l}\text { Otro plazo de } 40 \text { días, dividido en } \\
\text { dos pagos (el primer pago } 20 \text { días } \\
\text { antes del } 1 \text { de julio y el segundo } \\
\text { pago durante los } 20 \text { días siguientes } \\
\text { a esta fecha) }\end{array}$ & 6 monedas y un pedido & 15.000 .000 \\
\hline TOTAL & $\begin{array}{c}14 \text { monedas y dos } \\
\text { pedidos }\end{array}$ & 35.000 .000 \\
\hline
\end{tabular}

Ante estos datos cabe preguntarse que cantidad percibía la Corona por cada uno de los conceptos que componían el servicio (pedido y monedas). Por desgracia, lo habitual es que la documentación guarde silencio en torno a este asunto, como ocurre en el caso que aquí analizamos. Únicamente podremos hacernos una idea si atendemos a las referencias que contamos para otros años. Así, vemos como el pedido, cómo ya hemos indicado, solía suponer un mayor porcentaje del servicio de Cortes que las monedas, al menos desde la década de los treinta. Una circunstancia que se fue acentuando con el paso del tiempo, convirtiéndolo en un recurso cada vez más determinante $^{27}$. Ello permite adivinar que, seguramente, el pedido contó con una relevancia bastante superior a la de las monedas el año que aquí estudiamos. Así parece confirmarlo los datos parciales de algunos grandes partidos fiscales de la Corona, aunque éstos deben ser analizados con cuidado, ya que difieren mucho entre sí2 ${ }^{28}$. Afortunadamente, uno de estos partidos para los que disponemos de información es, precisamente, al que pertenecía la ciudad de Sevilla y su tierra $^{29}$ : el del arzobispado de Sevilla y el obispado de Cádiz. Allí las 14 monedas ascendieron a 906.798,4 maravedís (un 37,28\% del servicio pagado por esta demarcación fiscal) frente a 1.525.534 maravedís que supusieron los dos pedidos (el 62,71\%)

${ }^{26}$ Carta del pedido de 1454. AMS, Pap. May., Rollo 266, Caja 55, Pedido de 1454

${ }^{27}$ En 1445 el pedido regio suponía ya el 62,5\% del total del servicio. Para la evolución en importancia de este concepto véase RodRíguez SARRIA, “¿Cobrar para el rey?, p. 96

${ }^{28}$ Así puede observarse en la relación completa que disponemos para algunos años de lo que pagaba cada partido fiscal en el pedido y las monedas. El ejemplo más completo es el de los años 1442-1443 AGS, EMR, Leg 2, ff. 405r-456v.

${ }^{29}$ Contamos, así mismo, con documentación detallada en otros partidos de la Corona. Especialmente interesante resultan los padrones realizados para la recaudación de las monedas en Logroño, que fueron utilizados por los profesores Díaz de Durana y García Fernández para realizar una aproximación al estudio de la demografía de este Concejo. Díaz de Durana y García Fernández: Demografía y sociedad.

${ }^{30}$ AGS, EMR, Leg 6, ff. 265 r-v. 


\section{UN AÑO CONFLICTIVO EN EL PROCESO DE RECAUDACIÓN}

Tal y como señalamos a comienzo del presente estudio no es nuestra intención realizar aquí un análisis pormenorizado del funcionamiento del sistema de recaudación del pedido regio en Sevilla, labor que ya ha sido llevada a cabo por otros autores, sino observar ciertos aspectos de interés que no han recibido la suficiente atención hasta el momento. En este sentido, la documentación del año que aquí hemos elegido nos aporta una perspectiva privilegiada para lograr entender los serios problemas a los que tenía que hacer frente el citado procedimiento de recaudación a finales del reinado de Juan II. Así mismo, vemos como en éste se reflejan claramente esas las tensiones entre el monarca y las Cortes a las que hacíamos referencia anteriormente.

\subsection{LA INTERVENCIÓN REGIA EN EL PROCESO DE RECAUDACIÓN EN SEVILLA Y SU TIERRA}

El análisis del pedido de 1454 en Sevilla y su alfoz resulta un verdadero desafío para el investigador de este subsidio. Diversas circunstancias complicaron el proceso de recaudación este año hasta límites casi desconocidos hasta ese momento ${ }^{31}$. Las injerencias de la monarquía, el fallecimiento de Juan II y la creciente actitud de resistencia al pago de este subsidio por parte de la población pechera parecen ser algunas de las causas que permiten explicar esta circunstancia.

Para entender bien todo ello es necesario que retomemos el análisis de lo ocurrido tras la concesión de las Cortes y el establecimiento de los plazos en los que habían de recaudarse las catorce monedas y los dos pedidos de ese año. Tras adoptarse todas estas decisiones, vemos como los órganos centrales de la Hacienda establecieron las cantidades a recaudar en cada uno de los grandes partidos de la Corona ${ }^{32}$. Éstos estaban compuestos por una serie de unidades fiscales, que actuaban con independencia a la hora de organizar el proceso de recaudación de este subsidio ${ }^{33}$. Dichas unidades solían coincidir con los diferentes concejos y sus términos dependientes aunque, en ocasiones, podemos observar como aparecen también otro tipo de poblaciones como villas, monasterios, feligresías, etc ${ }^{34}$. La unidad fiscal que aquí centra nuestra atención, la de la ciudad de Sevilla y su tierra, era la que más contribuía de toda la Corona

31 Salvando algunos precedentes en la década de los cincuenta únicamente el año 1443 presenta problemas medianamente comparables con los de 1454. Pero sus causas son muy diferentes y se deben, más bien, a algunas transformaciones que tuvieron lugar en la geografía fiscal sevillana en estas fechas. AMS, Pap. May., Rollo 260, Caja 43, Pedido de 1443.

32 Para una imagen general de la geografía del pedido véase AguAdo GonzÁlez, "Fuentes para el estudio de la geografía administrativa" y TRIANo MiLÁn, "El arzobispado de Sevilla y el obispado de Cádiz", pp. 384385 .

${ }^{33}$ Una lista pormenorizada de éstas unidades fiscales, que contribuían de forma independiente al pago del pedido en el arzobispado de Sevilla y el obispado de Cádiz, la encontramos en Triano MiLÁn, "El arzobispado de Sevilla y el obispado de Cádiz" pp. 386-391.

${ }^{34}$ Por suerte, contamos con una completa relación de estas poblaciones en la única relación del pago del pedido que conocemos para toda la Corona, la del año 1455. AGS, EMR, Leg. 1, fols 455r-604r. Para una aproximación al estudio de este documento véase AGUADo GonZÁlEz, "Fuentes para el estudio de la geografía administrativa", pp. 465-480. 
en esta época ${ }^{35}$. Unos ingresos que se caracterizaban por su solidez ya que, tradicionalmente, las quiebras no solían ser excesivamente elevadas ${ }^{36}$ y el dinero no recaudado se amortizaba elevando la suma de la recaudación de posteriores pedidos ${ }^{37}$. Esta tendencia, sin embargo, parece que fue cambiando con el paso del tiempo:

Tabla 2. Evolución de la quiebra del pedido en Sevilla y su tierra

\begin{tabular}{|c|c|r|r|}
\hline Año & $\begin{array}{c}\text { Cantidad recaudada } \\
\text { (en mrs) }\end{array}$ & Quiebra (en mrs) & $\begin{array}{c}\text { \% de la quiebra sobre la } \\
\text { cantidad recaudada }\end{array}$ \\
\hline $\mathbf{1 4 3 2}^{\mathbf{3 8}}$ & 988.335 & 20.093 & 2,03 \\
\hline $\mathbf{1 4 3 8}^{\mathbf{3 9}}$ & 939.347 & $35.769,5$ & 3,81 \\
\hline $\mathbf{1 4 4 2}^{\mathbf{4 0}}$ & 914.265 & 43.699 & 4,78 \\
\hline $\mathbf{1 4 5 1}^{\mathbf{4 1}}$ & 351.340 & 27.074 & 7,70 \\
\hline
\end{tabular}

Que una región como ésta, que tan sólidos y cuantiosos ingresos aportaba a la Corona, empezara a mostrar dificultades para extraer unos recursos que eran cada vez más necesarios, generó una preocupación que no dejó de aumentar a lo largo de los años centrales del siglo. Y es que esta situación no sólo suponía un quebranto para la Real Hacienda sino que, además, era el reflejo de un problema mucho mayor: el deterioro generalizado del sistema de recaudación del servicio en toda la Corona. Así nos lo muestran las numerosísimas quejas de los procuradores de Cortes y los escasos datos cuantitativos conservados en el Archivo General de Simancas. De esta manera, si atendemos a la documentación del servicio de 1455-1456 vemos como de los 87.541.000 maravedís que habrían de haber sido recaudados de manera efectiva en el pedido y las monedas en este bienio, sólo 48.241 .000 de maravedís (el 41,81\%) llegaron a pagarse. El resto, 39.300 .000 maravedís $(55,10 \%)$ se acabaron descargando por diversos motivos:

35 El predominio de esta unidad fiscal sobre las otras existentes en la Corona se ve claramente en la relación del pedido de 1455 en Castilla. AGS, EMR, Leg. 1, fols 455r-604r.

${ }^{36}$ Así lo indicó Romero Romero, Sevilla y los pedidos de Cortes, p. 90.

${ }^{37}$ Existen abundantes ejemplos de ello. Baste señalar aquí como ejemplo los 59.300 maravedís que fueron destinados de la sobra del pedido de 1438 para pagar la quiebra de 1436. AMS, Pap. May., Rollo 259, Caja 41, Pedido de 1438.

38 AMS, Pap. May., Rollo 256, Caja 36, Pedido de 1432.

${ }^{39}$ AMS, Pap. May., Rollo 259, Caja 41, Pedido de 1438.

${ }^{40}$ AMS, Pap. May., Rollo 259, Caja 42, Pedido de 1442.

${ }^{41}$ Los datos que presentamos para 1451 son del "socorro" del pedido, cantidad que fue concedida por las Cortes tras observar que el servicio resultaba insuficiente para hacer frente a las necesidades de gasto existentes. AMS, Pap. May., Rollo 266, Caja 52, Pedido de 1451. 
Tabla 3. Descargo del servicio de $1455-1456^{42}$

\begin{tabular}{|l|r|r|}
\hline Descargos & Cantidad & Porcentaje \\
\hline Por lugares yermos & 1.300 .000 & 3,31 \\
\hline $\begin{array}{l}\text { Por villas y lugares privilegiados, con } \\
\text { franquezas o alguna suspensión }\end{array}$ & 4.000 .000 & 10,18 \\
\hline $\begin{array}{l}\text { Por suspensión de pagos de los pedidos } \\
\text { de Galicia y el obispado de Cartagena }\end{array}$ & 31.000 .000 & 78,88 \\
\hline $\begin{array}{l}\text { Por sumas no recaudadas en diversos } \\
\text { señoríos. }\end{array}$ & 3.000 .000 & 7,63 \\
\hline Total descargo & $\mathbf{3 9 . 3 0 0 . 0 0 0}$ & $\mathbf{1 0 0}$ \\
\hline
\end{tabular}

Como podemos apreciar la tradicional resistencia de algunos territorios, como es el caso del reino de Galicia ${ }^{43}$ y la negativa de algunos señores a contribuir en el pedido y las monedas eran las principales causas de que se dejaran percibir las sumas concedidas por las Cortes, amén de otros problemas como la falta de control sobre los lugares yermos de la Corona ${ }^{4}$. Por eso la atención de los procuradores de las ciudades y del monarca se centró en hacer frente a estos inconvenientes $\mathrm{y}$, sobre todo, a aquellos que empezaban a amenazar con dañar los ingresos de territorios fiscales en los que, tradicionalmente, el sistema de recaudación había funcionado bien.

En 1454 los problemas se hicieron patentes casi desde el mismo momento en que la maquinaria de extracción del pedido se puso en marcha. Los procuradores de la ciudad, Fernando de Medina y Fernando Ortiz ${ }^{45}$, caballeros veinticuatro, nombraron a los recaudadores mayores de este subsidio. Así fueron designados Alfón de Baeza, Pedro López Serrano y Juan Sánchez de Sevilla ${ }^{46}$, que ya habían sido recaudadores mayores del servicio en este partido fiscal en $1453^{47}$. Su obligación era actuar como los máximos encargados de la recaudación del pedido y las monedas ${ }^{48}$ en todo el arzobispado de Sevilla y el obispado de Cádiz y convertirse en el elemento de conexión entre las distintas unidades fiscales del partido y los órganos centrales de la Hacienda regia.

Este año la labor de estos individuos apenas ha dejado rastro en la documentación de la que disponemos. Todo parece indicar que, por razones que nos son desconocidas, su nombramiento se retrasó más de lo habitual. Para hacer frente a este problema la ciudad decidió a nombrar una serie de receptores que se hicieran cargo del proceso

${ }^{42}$ AGS, EMR, Leg. 9, f. 8r-v.

43 Rubio Martínez, "Los ingresos extraordinarios...” pp. 232 y ss.

${ }^{4}$ Este problema era una preocupación de los procuradores, al menos, desde 1438, cuando se solicitó en las Cortes de Madrigal que se hiciera pesquisa de los lugares yermos del reino. Posteriormente, se incidirá en la necesidad de adoptar medidas en este sentido de manera periódica, al parecer con escaso éxito.

45 Sobre estos procuradores de Sevilla contamos con una detallada información en SÁNCHEZ SAUS, Caballería y linaje, pp. 267-269 y pp. 334-336.

46 Tenemos la suerte de que los nombramientos de los recaudadores por parte de los procuradores de Sevilla se conserven para este año. AGS, EMR, Leg 4, ff. 282r-v y 287r-v.

47 AGS, EMR, Leg. 4, ff. 283r. y 290r.

48 No siempre el recaudador mayor recaudaba la totalidad del servicio de Cortes en el partido en el que actuaba. Hay algunos años en las que se nombran recaudadores independientes para las monedas y el pedido en algunos partidos fiscales. Triano MiLÁN “El Arzobispado de Sevilla y el Obispado de Cádiz”, p. 362. 
de recaudación mientras tanto ${ }^{49}$. Una medida que llama poderosamente la atención, ya que el cargo de receptor del pedido y las monedas resulta poco usual en la ciudad de Sevilla. Éste solamente aparece cuando existe algún problema en el proceso de recaudación o, por alguna razón, el recaudador mayor no puede desempeñar sus funciones $^{50}$. Su existencia es una pista clara, por tanto, de que algo no funciona correctamente en la extracción de los ingresos de la ciudad hispalense y su alfoz, ámbito en el que estos agentes fiscales actúan ${ }^{51}$. Parece que la presencia de estos receptores fue algo común en la primera mitad de años cincuenta, ya que contamos con testimonios que nos indican que también se recurrió a su participación en el proceso de recaudación del año $1451^{52}$.

La dificultad de la labor a la que tenían que hacer frente estos individuos resulta evidente. Es por ello que se solía recurrir a figuras con una amplia experiencia en negocios financieros y que gozaban de la total confianza del Concejo hispalense. Un perfil muy similar al que presentaban los recaudadores mayores ${ }^{53}$.

En concreto vemos que en 1454 fueron designados para ejercer este oficio Pedro de Priego, Gómez de Herrera y Alvar Gómez de Córdoba ${ }^{54}$. Los dos primeros eran reconocidos financieros con una larga tradición en el arrendamiento de rentas municipales en territorio sevillano, mientras que el último, además de participar en este tipo de negocios, también había ejercido importante papel dentro del ayuntamiento hispalense, como mayordomo de la ciudad ${ }^{55}$

Señalábamos anteriormente que las causas que determinaron el retraso del nombramiento de los recaudadores nos son desconocidas, ya que no hay ninguna referencia a este aspecto en la documentación. No obstante, visto lo que conocemos sobre las tensiones existentes entre Cortes y monarca en estos momentos creemos que no es descabellado plantear la posibilidad de que fuera esta circunstancia, precisamente, la que dio lugar a dicho retraso. Juan II ya había intervenido directamente sobre los procesos de recaudación anteriormente, atentando contra los derechos de los procu-

49 AMS, Pap. May., Rollo 266, Caja 55, Pedido de 1454.

50 Esta fue la tendencia general a lo largo del siglo XV. No obstante, a partir de la reforma introducida por los Reyes Católicos en 1476 vemos como los recaudadores mayores serán sustituidos por receptores. Éstos tendrán un carácter distinto a los agentes fiscales que ejercieron su cargo con anterioridad en territorio sevillano, ya que llevarán a cabo sus funciones en todo el partido fiscal y serán designados directamente por los procuradores de Cortes y no por el Concejo. AGS, EMR, Leg. 19, f. 37r-v.

51 Así lo indica el nombramiento de Alvar Gómez de Córdoba "mandaron a vos lo contadores hicierdes luego repartimieto de los dichos mrs que montan todo el dicho pedido para esta ciudad y por las villas y lugares de su tierra, para las cuantías que ahora en este dicho año pasado se hicieron para pagar el pedido del año pasado [...] Mandaron que hagades cargo de todos los dichos mrs que así repartades, al dicho Alvar Gómez de Córdoba al cual la dicha ciudad nombro y nombra receptor de todo ello". AMS, Pap. May., Rollo 266, Caja 55, Pedido de 1454.

52 AMS, Pap. May., Rollo 266, Caja 52, Pedido de 1451.

53 De hecho, no era infrecuente que algunas personas llegaran a desempeñar ambos cargos. Este es el caso de Ruy González de Sevilla, que actuó como recaudador mayor del pedido en 1445 y como receptor de este subsidio en 1451. AMS, Pap. May., Rollo 266, Caja 52, Pedido de 1451.

54 AMS, Pap. May., Rollo 266, Caja 55, Pedido de 1454.

55 Collantes De Terán SÁnchez, "La élite financiera en la Sevilla bajomedieval”, p. 33 
radores $^{56}$, por lo que es plausible que hubiera planteado algún tipo de resistencia a que éstos nombraran a los recaudadores mayores. Esta hipótesis parece reforzarse si tenemos en cuenta lo que ocurrió justo a continuación de la llegada de estos agentes fiscales a la ciudad hispalense.

Una vez en Sevilla, estos recaudadores deberían haber podido hacerse cargo de la recaudación del pedido en estrecha colaboración con el Concejo de la ciudad ${ }^{57}$ pero, en la práctica, ello no fue posible. La causa fue la aparición de otro problema imprevisto: el proceso de cobro quedó bajo el control de aquellas personas que debían percibir ciertos libramientos sobre el pedido y las monedas. En concreto, la documentación nos informa de la presencia en la ciudad del Betis de dos beneficiarios de estos libramientos: Gonzalo de Alba y Fernando González de Madrid ${ }^{58}$. El primero de ellos era repostero de camas de Juan II, puesto que seguramente le proporcionaría una gran cercanía al monarca. Así mismo, conocemos también su estrecha y fructífera relación con el conde de Alba ${ }^{59}$. De Fernando González de Madrid sabemos bastante menos. Sólo podemos destacar aquí su actividad como escribano de las Cortes junto a Pedro Sánchez del Castillo durante el reinado de Enrique IV de Castilla ${ }^{60}$.

Normalmente, estas personas hubieran tenido que esperar a que los recaudadores mayores cosecharan las sumas repartidas con la ayuda del Concejo de la ciudad para hacer efectivo el pago. Pero, en esta ocasión, acabaron interviniendo directamente en el proceso de recaudación gracias a la capacidad que el rey les otorgó para ello. Así lo observamos en la carta de libramiento destinada a Fernando González de Madrid:

[...] manda que el dicho Fernando González, o el que su poder hubiere, puedan repartir por esta çibdad y por las villas y logares de su tierra y del dicho su arzobispado y por cualquier o cualesquier de ellas, según y el bien visto fuere y entendiere que cumple porque mas prestamente los pueda haber y cobrar, para hacer y cumplir lo que por la merced del rey le es mandado ${ }^{61}$

Por su parte, a Gonzalo de Alba se le indicó inicialmente que las cantidades que había de percibir le serían libradas por los recaudadores mayores del pedido, como era usual. Sin embargo, sus quejas ante la lentitud con la que actuaban los citados recaudadores llevo al soberano a ordenar que el repostero de camas pudiera repartir y cobrar las cantidades que le quedaban por percibir o pudiera designar a una persona que lo hiciera en su nombre ${ }^{62}$.

56 Así se muestran en algunas peticiones al monarca, como las incluidas en el otorgamiento del pedido de 1448. Olivera Serrano, Las Cortes de Castilla y León, pp. 205 y ss.

57 Algunas reflexiones sobre estos recaudadores y su particular relación con el concejo de la ciudad fueron analizados por Romero Romero, "El Concejo como instrumento de la fiscalidad regia", pp. 162-163

58 AMS, Pap. May., Rollo 266, Caja 55, Pedido de 1454.

59 CoOper, "La Iglesia y los comuneros", p. 281.

${ }^{60}$ Carretero Zamora, Cortes, Monarquía, ciudades, p. 42.

${ }^{61}$ AMS, Pap. May., Rollo 266, Caja 55, Pedido de 1454.

62 “.... y porque mi merçed y formal intención es que los dichos mrs que yo así mandé librar al dicho Gonzalo de Alba, se reciban y cobren antes que otros ningunos [...] mando al dicho mi recaudador que si algunos mrs ha recibido de los dichos pedidos y monedas, que acuda luego con ellos al dicho Gonzalo de Alba, o al que su poder hubiere, para en cuenta de los mrs que en él le mande librar como dicho es, y los mrs restantes 
De esta manera, Juan II volvía a atentar contra la teórica capacidad de los procuradores de Cortes de controlar la recaudación del subsidio, al desplazar en sus funciones a los recaudadores mayores y colocar en su lugar a figuras cercanas a su persona. En la práctica fueron diversos agentes designados por Fernando González de Madrid y Gonzalo de Alba los que acabaron dirigiendo los diversos repartimientos realizados en Sevilla y su tierra en los que se acabó recaudando la totalidad del pedido:

Tabla 4. Resumen ingresos del pedido en Sevilla y su tierra en $1454^{63}$

\begin{tabular}{|l|r|l|}
\hline Concepto & Ingreso (en mrs) & Observaciones \\
\hline $\begin{array}{l}\text { Repartimiento de Gonzalo } \\
\text { de Oviedo }{ }^{64}\end{array}$ & $598.290,50$ & $\begin{array}{l}\text { A esta cifra se unen los 96.709,5 maravedís } \\
\text { que cobró sobre las monedas de Sevilla y su } \\
\text { tierra este personaje. Lo que da un total de } \\
695.000 \text { maravedís en este repartimiento. }\end{array}$ \\
\hline $\begin{array}{l}\text { Repartimiento de Gonzalo } \\
\text { Fernández de Madrid }\end{array}$ & $170.000,00$ & \\
\hline $\begin{array}{l}\text { Cantidad recaudada por los } \\
\text { receptores del pedido }\end{array}$ & $18.230,00$ & \\
\hline TOTAL & $\mathbf{7 8 6 . 5 2 0 , 5 0}$ & \\
\hline
\end{tabular}

Todos estos cambios no podían de dejar de afectar al proceso de recaudación, y lo hicieron de forma negativa. La resistencia de los recaudadores mayores a ceder su posición a los libradores acabó retrasando el proceso de repartimiento y extracción de los recursos. Así mismo, la falta de una organización clara a la hora de actuar por parte de estos libradores dio lugar a ciertos conflictos. Ello queda claramente reflejado en el enfrentamiento mantenido entre Gonzalo de Alba y Fernando González de Madrid acerca de cual de ellos tenía prioridad a la hora de recibir las cantidades que les habían sido asignadas, lo que obligará al Concejo de la ciudad a mediar entre ambos y elevar una consulta al rey ${ }^{65}$.

Las dificultades no acabaron aquí. La muerte de Juan II y el ascenso al trono de Enrique IV afectaron de manera significativa a la recaudación del pedido. El nuevo monarca ordenó que se produjese el embargo de las sumas recaudadas por parte de los concejos y que éstos no librasen ninguna cantidad hasta que él mismo diese autorización ${ }^{66}$. Finalmente, vemos como, en el caso de Sevilla, acabó dando el visto bueno a Gonzalo de Alba para que se hiciese cargo del dinero que aún se le debía. Pero la resistencia de la población a hacer efectivo el pago del pedido se vendría a sumar a las dificultades ya explicadas, alargando aún más un proceso que presentaba ya un evidente retraso.

mi merçed y voluntad es que el dicho Gonzalo de Alba, o el que su poder obiese, lo reparta y recaude segúnd y cómo en las dichas mis sobrecartas se contiene". AMS, Pap. May., Rollo 266, Caja 55, Pedido de 1454.

${ }^{63}$ Ibid.

${ }^{64}$ Persona nombrada por Gonzalo de Alba. No obstante, este repartimiento se hace en nombre de Gonzalo de Alba (500.000 maravedís) y Fernando González de Madrid (195.000 maravedís).

${ }^{65}$ AMS, Pap. May., Rollo 266, Caja 55, Pedido de 1454.

${ }^{66}$ Así se observa en la carta de confiscación del pedido. AMS, Pap. May., Rollo 266, Caja 55, Pedido de 1454. 


\subsection{RESISTENCIAS AL PAGO DEL PEDIDO}

Las referencias a los constantes problemas a los que tuvieron que hacer frente Gonzalo de Alba y las figuras por él nombradas para asumir la recaudación del pedido en Sevilla y su tierra en 1454 abundan en la documentación que ha llegado hasta nosotros. Estas dificultades, aunque posiblemente potenciadas por las tensiones entre el monarca y las ciudades este año, no son algo puntual, sino el producto de unos problemas originados mucho tiempo atrás. Pese a que, como hemos señalado, el proceso recaudatorio en Sevilla y su tierra se caracterizó, al menos hasta los años cincuenta, porque las sumas demandadas solían ser pagadas dentro de un plazo razonable y casi en su totalidad, también es cierto que existieron ciertas fallas en el sistema de extracción de recursos desde su origen. Si bien éstas no fueron demasiado importantes en un primer momento, lo cierto es que, con el paso del tiempo, fueron aumentando y convirtiéndose en un problema cada vez más serio, tal y como se refleja en el hecho de que las quiebras del pedido aumentaran inexorablemente a lo largo de toda la primera mitad del siglo $\mathrm{XV}^{67}$. Una de las principales causas que determinó esta evolución fue la creciente actitud de resistencia que buena parte de la población pechera mantuvo con respecto al pago del pedido regio. Una resistencia que fue especialmente intensa en el caso de la aristocracia sevillana y de aquellos individuos que abusaron de su condición de exentos de determinados pechos reales y concejiles, tratando de hacer extensivos éstos al pago del subsidio que aquí ocupa nuestra atención.

Con respecto a la oposición al pago del pedido regio por parte de la aristocracia sevillana, parece que esta actitud fue el producto de una sensación de agravio al verse obligados a contribuir a esta ayuda. Teóricamente los grupos privilegiados se encontraban exentos del pago del pedido ${ }^{68}$, pero en Andalucía la proximidad de la amenaza musulmana había llevado a que dicho privilegio no fuese respetado. Así nos lo muestra el cuaderno de Cortes de 1442, donde se indica que en Andalucía: "todos comúnmente pechan, así ricos omes como caballeros, fijosdalgo, e otros qualesquier, lo qual se acostumbro siempre asi fazer por el bien comun e defension de aquella tierra" ${ }^{99}$. El verse obligados a pagar el pedido creó una fuerte insatisfacción en la aristocracia hispalense, tal y como se refleja en sus constantes protestas y las peticiones para que se les diese trato similar al que disfrutaba el estamento nobiliario en otras partes de Castilla. En este sentido, podemos señalar la solicitud que en 1436 realizaron los caballeros, dueñas y escuderos de la ciudad para no contribuir, indicando que así lo marcaba la tradición ${ }^{70}$. Sin embargo, la negativa de la Corona a considerar este tipo de peticiones se mantuvo siempre y la nobleza siguió pagando,

67 Véase cuadro 2.

68 Esta circunstancia quedo reflejada, usualmente, en la carta del pedido: “ [...] que paguen todas las personas vecinos y moradores en esta dicha ciudad y villas y lugares de su tierra, y cada uno de ellos esentos e no esentos salvo caballeros, escuderos y dueñas y doncellas, hijosdalgos de solar conocido o que es notorio que son hijosdalgos, y los que mostraren que son dados por hijosdalgos por sentencia en las cortes de cualquier de los reyes donde yo vengo oídos con su procurador fiscal o en la mi corte con mi procurador fiscal, y las mujeres e hijos de estos atales, y los clérigos de misa y de orden sacra” AMS, Pap. May., Rollo 257, Caja 39, Pedido de 1436.

69 Citado por Ladero Quesada, La Hacienda Real de Castilla, p. 211.

70 AMS, Pap. May., Rollo 257, Caja 39, Pedido de 1436. 
aunque en menor medida de lo que habría debido hacerlo en virtud de la importancia de sus haciendas. Ello fue posible gracias a la connivencia del Concejo de la ciudad, que ejercía un control directo sobre los procesos de repartimiento y recaudación del pedido $^{71}$. Aún así, esto no aplacó el sentimiento de la nobleza de estar siendo objeto de una grave injusticia, ya que el simple hecho de pagar suponía un atentado contra su estatus. Todo ello dio lugar a una clara actitud de resistencia, con la que difícilmente podían lidiar los regidores del Concejo. Éstos, afectados también por la normativa, mostraron cierta desidia a la hora de actuar contra este tipo de prácticas, que se convirtieron en algo habitual ${ }^{72}$ Así se refleja, por ejemplo, en las quejas de algunos jurados elevaron a esta institución en 1442, en las que indicaban lo frecuentes que eran las negativas y dilaciones que los aristócratas que residían en la ciudad mostraban a la hora de pagar a los cogedores del subsidio ${ }^{73}$.

Más graves, por el impacto que supusieron para la recaudación del pedido, resultaron los problemas a los que dieron lugar los exentos de la ciudad de Sevilla y su tierra. Aunque en un primer momento la Corona trató de proteger al pedido de la carga que dichas exenciones podían suponer para el proceso de recaudación ${ }^{74}$ prohibiendo cualquier tipo de franqueza ${ }^{75}$, finalmente la mayor parte de las exenciones de origen regio acabaron siendo confirmadas ${ }^{76}$. Éstas, sin embargo, no suponían una carga demasiado elevada por sí solas. El verdadero problema vino de la gran cantidad de abusos que se acabaron cometiendo en relación a la condición de exento. Fueron muchos los que se hicieron pasar por tales sin serlo realmente, al tiempo que aquellos que sí contaban con franquezas para determinados pechos hicieron extensivas éstas al pedido, pese a la patente ilegalidad que ello suponía ${ }^{77}$. Así mismo, fue frecuente que instituciones como el propio Concejo de la ciudad, los nobles o la Iglesia nombrasen exentos

${ }^{71}$ Este aspecto ha sido analizado en detalle en RodríGuez SARRIA, "Fisco, poder y distinción social" (en prensa).

72 Así lo muestra la petición al conde de Niebla para que contribuyese en el pedido de 1432. Éste acaba aceptando pagar, pero recalcando que lo hacía solo porque era su voluntad: "[...] el dicho Gonçalo Gonçalez jurado, dixo al dicho sennor conde que le pedía por merçed que le mandase pagar los quatro mil maravedies quele copiese a pagar de este pedido [...] a lo que el dicho sennor conde respondio luego que a el que le plasia de los pagar". Citado por Romero Romero, Sevilla y los pedidos de Cortes, pp. 84-85.

73 "E otrosí los susodichos maestres e ricos omes e caualleros e familiares no pagan ellos e no quieren pagar el dicho pedido [...]" AMS, Actas Capitulares, Rollo 3, Caja 4, Carpeta 22, ff 6-7 (en adelante Act. Cap.)

${ }^{74} \mathrm{El}$ ejemplo de lo ocurrido con otros ingresos de la Corona, muy mermados a causa de las abundantes exenciones que se habían ido concediendo fue lo que determinó que se adoptase esta decisión. Un caso paradigmático en este sentido es el de las monedas. De hecho, creemos que la aparición del pedido en 1406 se encuentra estrechamente vinculada a la incapacidad de las monedas de recaudar las sumas que la Monarquía necesitaba precisamente por esta causa.

75 " [...] ninguna ni alguna persona de qualquier estado o condiçion no se puedan escusar ni escusen de pagar los mis pedidos por cartas ni preuillejos solamente valan e lo sean guardados en las monedas e esto solamente aquellos que estan puestos e asentados en lo saluado en el mi quaderno delas monedas e no otros algunos" AMS, Diversos, Rollo 742, Documento 203.

${ }^{76}$ Romero Romero, Sevilla y los pedidos de Cortes, p. 20 y Rodríguez Sarria, "Fisco, poder y distinción social".

${ }^{77}$ Un claro ejemplo de ello es el de los familiares de la Iglesia, aspecto estudiado por el profesor CoLLANTES De Terán SÁnchez, Sevilla en la Baja Edad Media, pp. 249 y ss. 
sin contar con la capacidad para ello $^{78}$. De esta manera, vino a aumentar de forma constante el número de individuos que sostenían tener derecho a no contribuir a esta ayuda, especialmente entre personas acomodadas o de cierta relevancia económica ${ }^{79}$. Esto hacía recaer la carga del pedido sobre un grupo de contribuyentes cada vez más reducido, lo que acabó afectando gravemente al proceso de recaudación. Ante esta situación la Corona se vio obligada a adoptar una serie de medidas restrictivas en relación a las exenciones que, no obstante, acabó fracasando.

Junto a estas resistencias otros aspectos, como las frecuentes prácticas fraudulentas llevadas a cabo los agentes fiscales ${ }^{80}$, se hacían cada vez más patentes, al tiempo que el sistema de recaudación del pedido empezaba a mostrar evidentes signos de agotamiento. Circunstancia que impidió a Gonzalo de Alba desempeñar su labor de forma correcta en 1454 y le obligó a designar a Pedro de Segovia ${ }^{81}$ y Juan de la Peña ${ }^{82}$ para que se hicieran cargo de la misma en su nombre ${ }^{83}$. Teóricamente serían ellos los que pondrían fin al proceso recaudatorio que se había alargado casi un año más de lo usual a causa de los hechos aquí explicados. Pero referencias en documentación posterior nos hace ver que, en realidad, dicho proceso no tuvo un final exitoso. Aún en 1462 el repostero de camas seguía insistiendo para que se le pagasen los maravedíes que, pese a sus esfuerzos, no habían llegado a sus manos en $1454^{84}$.

78 “[...] a mi es fecha rrelación de que algunas personas poderosas e conçejos e vniversidades e otros qualesquier quier, en mi desseruiçio e en gran dagno e perjuiçio de los conçejos e vezinos e moradores pecheros delas çibdades e villas e logares delos dichos mis rregnos, han escusado o escusan de cada dia muchos delos pecheros delas dichas çibdades e villas e logares, asi delas monedas commo del pedido e de otros quales quier pechos rreales e conçejales, deziendo ser sus escusados o en otras maneras [...]"Cortes de los antiguos reinos de León y de Castilla, vol. III, pp. 104-105. (en adelante Cortes)

79 Pese a la prohibición de que los individuos de mayor cuantía no pecharan en el pedido, parece ser que esta situación se producía con cierta frecuencia. Así se señala con respecto a los familiares de la Iglesia: "Otrosí muy esclarecido rey e señor por que algunas personas e universidades e monesterios e otros logares e presonas eclesiasticas especialmente el Arçobispo e Dean e Cabildo e clerigos de la çibdad de Seuilla han escusado y escusan de cada dia muchos delos pecheros [...] diziendo ser sus escusados, escusando homes de muy grandes faciendas, e fallará vuestra señoria que clerigo hay en Seuilla que no tiene hacienda de dosçientas doblas e tiene tres o cuatro escusados de hacienda de tres o quatro mill doblas cada uno" Cortes, III, pp. 679 y ss.

${ }^{80}$ Las quejas en torno a ello son muy frecuentes en las Actas de Cortes. "[...] los tales rrecabdadores escuçan o han escuçado delos dichos tiempos aca muchos pecheros llanos por ser sus parientes e amigos allegados a algunos sennores e caualleros con que los tales rrecabdadores e arrendadores biven, lo qual se carga sobre los otros que llana mente pagan a vuestra alteza el pedido a muchos pecheros llanos". Cortes III, pp. 238 y ss.

81 De Pedro de Segovia únicamente conocemos su oficio en la Corte: portero de Cámara. Será él, además, uno de los recaudadores del pedido de 1455-1456. AGS, EMR, Leg. 5, ff. 218r-219v

82 Juan de la Peña, escudero de caballo del rey, había desempeñado importantes cargos bajo el reinado de Juan II. Así, por ejemplo lo encontramos actuando como embajador ante la Corte nazarí de Granada junto a un tal Luis González en 1439. Peláez Rovira, El emirato nazarí de Granada, p. 194.

83 AMS, Pap. May., Rollo 266, Caja 55, Pedido de 1454.

${ }^{84}$ AGS, EMR, Leg. 10, ff. 3r-15v. 


\section{EL GASTO}

Una vez analizada la concesión y recaudación del pedido en 1454, queda centrar nuestra atención en el destino que acabó teniendo este dinero. En un sistema fiscal como el de la época que aquí estudiamos, en el que es el gasto el que determina la política de ingresos y no al revés ${ }^{85}$, este aspecto se convierte en el eje fundamental en torno al que se articula el funcionamiento de las diversas figuras impositivas y los distintos subsidios que nutren a la Hacienda regia. El pedido regio no es una excepción en este sentido, por lo que, si queremos profundizar en su conocimiento, habremos de incidir en el análisis del gasto. Sin embargo, éste resulta mucho más difícil de estudiar que el ya citado proceso de concesión y recaudación. El silencio de la documentación al respecto suele ser casi absoluto y sólo los documentos de otorgamiento y algunas referencias dispersas nos permiten hacernos una idea en este sentido. No obstante, 1454 es una excepción a esta tendencia, ya que en el libro de pedido de este año se ha conservado una pormenorizada relación de las partidas a las que fue destinado el dinero recaudado en la ciudad hispalense y su alfoz:

Tabla 5. Libramientos sobre el pedido en Sevilla y su tierra en $1454^{86}$

\begin{tabular}{|l|l|r|r|}
\hline Librador & Partida & Mrs Corona & Mrs Sevilla y su alfoz \\
\hline \multirow{2}{*}{ Gonzalo de Alba } & Guerra & 10.000 .000 & 420.000 \\
\cline { 2 - 4 } & $\begin{array}{l}\text { Construcción del } \\
\text { Monasterio de } \\
\text { Miraflores (Burgos) }\end{array}$ & 500.000 & 210.000 \\
\hline \multirow{2}{*}{$\begin{array}{l}\text { Fernando González } \\
\text { de Madrid }\end{array}$} & $\begin{array}{l}\text { "Sobreseimiento" de la } \\
\text { guerra }^{87}\end{array}$ & 3.000 .000 & 170.000 \\
\cline { 3 - 4 } & \multicolumn{1}{|c|}{ Total } & $\mathbf{1 3 . 5 0 0 . 0 0 0}$ & 195.000 \\
\hline
\end{tabular}

Si analizamos con atención el cuadro el primer hecho que llama nuestra atención es que las sumas libradas en esta unidad fiscal son superiores a las recaudadas este año. Es por ello que, finalmente, de los 995.000 maravedís que se libran sobre Sevilla y su tierra parte acaban siendo pagados sobre las sumas repartidas en las 14 monedas (96.709,5 maravedís) y una importante cantidad, 130.000 maravedís, ni siquiera se pueden cobrar, ya que no "caben". El dinero que no puede ser recaudado acaba siendo reconocido como deuda a Gonzalo de Alba por el Concejo de Sevilla. Éste, dadas las dificultades para ingresar las sumas repartidas en el pedido este año y el hecho de que parte del dinero que necesitaba ni siquiera había podido ser repartido, posiblemente se vio obligado a adelantar los maravedís necesarios para hacer frente a aquellas partidas que demandaran una mayor urgencia.

85 Galán Sánchez, y Carretero Zamora, El alimento del Estado, pp. 7 y ss.

${ }^{86}$ AMS, Pap. May., Rollo 266, Caja 55, Pedido de 1454.

${ }^{87}$ El 7 de diciembre de 1453 se había dispuesto un "sobreseimiento" de la guerra entre Castilla, Aragón y Navarra Vincens Vives, Juan II de Aragón, p. 166. 
Como vemos, el pedido fue insuficiente para hacer frente a las elevadas necesidades del gasto de este año. De hecho, conocemos dos partidas más que se pretendió costear con este subsidio en Sevilla en 1454 pero que, una vez que se comprobó que no cabian, acabaron pagándose con las sumas cosechadas en las 14 monedas repartidas en la ciudad hispalense y su alfoz. Así, a Per Afán de Ribera, adelantado mayor de la frontera, se le libran 191.920 maravedís en la ciudad y su tierra para el pago de la gente a caballo y de a pie que reunió en Sevilla y otras partes de Andalucía desde principios de noviembre de 1453 hasta finales de 1454. A ello hay que añadir tres libramientos para el pago de mercedes regias, que ascendieron a un total de 28.000 maravedís ${ }^{88}$. Como podemos observar, todo parece indicar que el pedido a duras penas podía hacer frente a unas necesidades muy elevadas y heterogéneas.

Un simple vistazo a las partidas de gasto que aquí hemos mencionado, tanto aquellas que fueron costeadas por el pedido como por las monedas, nos permitirá entender uno de los aspectos que mayor tensión despertó entre las ciudades y el monarca a lo largo del siglo XV: el destino efectivo que se le dio al dinero concedido en el servicio de Cortes. Usualmente, las cantidades demandadas por el rey lo eran en virtud a la necesidad de defensa del reino ante una amenaza exterior, la de asegurar el bien común, la de garantizar la seguridad pública u organizar la lucha contra el infiel ${ }^{89}$.

Tabla 6. Causas aducidas para la solicitud del servicio de Cortes (1406-1476) ${ }^{90}$

\begin{tabular}{|c|c|}
\hline Año & Causa \\
\hline $1408-1409$ & Guerra contra Granada \\
\hline 1411 & Guerra contra Granada \\
\hline 1419 & Armada en ayuda del rey de Francia \\
\hline 1420 & Armada en ayuda del rey de Francia \\
\hline 1425 & Preparación conflicto con Aragón \\
\hline 1429 & Guerra contra Granada \\
\hline 1430 & - \\
\hline 1431 & Guerra con Granada \\
\hline 1432 & - \\
\hline 1433 & - \\
\hline 1434 & - \\
\hline 1435 & Pago de la gente de armas que había luchado en Granada \\
\hline 1436 & - \\
\hline 1438 & - \\
\hline 1440 & \\
\hline
\end{tabular}

${ }^{88}$ AMS, Pap. May., Rollo 266, Caja 55, Pedido de 1454.

${ }^{89}$ Sobre la justificación doctrinal para este tipo de demandas a las Cortes contamos con el magnífico estudio de Ortego Rico, "Justificaciones doctrinales de la soberanía fiscal regia"

${ }^{90}$ Relación realizada en base a Ladero Quesada, La Hacienda real de Castilla, p. 220; las cartas de otorgamiento publicadas por Olivera Serrano, Las Cortes de Castilla y León; y las distintas cartas del pedido conservadas en la sección de Pap. del May. del AMS. Como se puede observar no disponemos de datos exactos para todos los años. 


\begin{tabular}{|c|c|}
\hline 1442 & $\begin{array}{c}\text { Pago de la tregua con Granada, los daños ocasionados por la guerra, la } \\
\text { herencia de la hermana del rey y el mantenimiento de los castillos fronteros. }\end{array}$ \\
\hline 1443 & $\begin{array}{c}\text { Acuñación de moneda, pago de castillos fronteros e intervención en } \\
\text { Portugal. }\end{array}$ \\
\hline 1444 & - \\
\hline 1445 & - \\
\hline 1447 & Guerra con Navarra, rebelión de Murcia, proyecto de matrimonio real y \\
apoyo al rey de Granada.
\end{tabular}

Sin embargo, y pese al juramento que solía prestar el rey de destinar el dinero que le había sido concedido únicamente en aquellos asuntos para los que se le otorgaban estas sumas, éste era gastado en partidas no admitidas por los procuradores de Cortes. Así lo vemos claramente en el servicio de este año. A pesar de las promesas de Juan II en el documento de otorgamiento ${ }^{91}$, se hace patente como parte significativa del dinero recaudado en Sevilla se destina a la construcción del monasterio de Miraflores, donde había de ser sepultado el monarca ${ }^{92}$. Así mismo, existe otra partida no aprobada, la que con el dinero de las monedas costea diversas mercedes de la ciudad, que nos plantea una situación aún más grave. No sólo se estaban destinando los recursos extraordinarios de la Corona para hacer frente a gastos no admitidos por aquellos que los concedían sino que, además, éste se estaba utilizando para costear gastos ordinarios.

91 Olivera Serrano, Las Cortes de Castilla y León, pp. 249 y ss.

92 Del Arco Y Garay, Sepulcros de la Casa Real de Castilla, pp. 337 y ss. 
Todo esto es una clara muestra la creciente incapacidad de la monarquía para sufragar sus necesidades habituales con los ingresos que percibía habitualmente. Las causas de ello son de sobra conocidas. Mientras los recursos ordinarios de la Corona tendían a estancarse o, incluso a retroceder, sus gastos no dejaban de aumentar ${ }^{93}$. Ante esta situación sólo había una salida: sanear el sistema impositivo reduciendo el enorme situado existente. Pero esta vía no fue adoptada de forma seria durante el reinado de Juan II y mucho menos durante el de su hijo, Enrique IV. Solamente quedaba, por tanto, buscar fuentes de ingresos que permitieran hacer frente a las acuciantes dificultades financieras de la Corona. Por eso se decidió optar por recurrir, de manera cada vez más frecuente, a los recursos extraordinarios, que parecían mostrar aún cierto dinamismo y capacidad de crecimiento. Dentro de éstos el pedido y las monedas eran los más relevantes y accesibles para el monarca ${ }^{94}$. Un único escollo que se interponía entre el rey y las ansiadas sumas que se podía percibir a través del servicio de Cortes: la posible resistencia que planteaban los procuradores a la hora de conceder las cantidades demandadas. Pero para hacer frente a esta oposición se desarrollaron una serie de instrumentos que aumentaron el ascendiente del monarca sobre las Cortes. Uno de los más efectivos fue el de vincular el salario de los procuradores a las arcas reales ${ }^{95}$ primero y, posteriormente, a las cantidades recaudadas en el pedido y las monedas. El aumento constante del gasto en los emolumentos ${ }^{96}$ de estos personajes favoreció que las negativas a las peticiones del monarca fueran cada vez más débiles.

Tabla 7. Libramientos sobre el pedido y las monedas destinados al pago de los procuradores de Cortes $^{97}$

\begin{tabular}{|r|r|r|r|}
\hline Año & Concesión $^{\mathbf{9 8}}$ & $\begin{array}{c}\text { Cantidad destinada a los } \\
\text { procuradores }\end{array}$ & \% del total \\
\hline 1447 & 60.000 .000 & 700.000 & 1,16 \\
\hline 1451 & $50.000 .000+2.000 .000$ & 600.000 & 1,15 \\
\hline 1462 & 86.000 .000 & 3.280 .000 & 3,81 \\
\hline 1469 & 93.000 .000 & 4.100 .000 & 4,40 \\
\hline 1473 & $93.000 .000+30.000 .000$ & 5.800 .000 & 4,71 \\
\hline
\end{tabular}

93 Round, The greatest man uncrowned, pp. 51 y ss.

94 Pero no los únicos. Existen referencias al uso de otros importantes recursos extraordinarios de la Corona para hacer frente a sus necesidades ordinarias. Así, por ejemplo, sabemos que la Bula de Cruzada concedida apenas un año después de los acontecimientos aquí relatados acabó teniendo un destino muy diferente al que debería de haber tenido. "Fue tan grande el dinero que por virtud desta bula de Cruzada se ovo para el rey durante el tienpo de los quatro años en ella contenidos, que se afirma por los thesoreros e reçebtores della que pagadas sus despenssas vinieron a poder del rey mas de çient cuentos, de los quales muy poca parte se gasto en la guerra de los moros, de lo qual todos los grandes del reyno fueron mucho turbados". Crónica anónima de Enrique IV, pp. 66 y ss.

95 La decisión de que el salario de los procuradores procediera de las arcas reales se adoptó en las Cortes de Ocaña de 1422. VAldeón BARUQue, "Las Cortes de Castilla", p. 310.

96 Un estudio general sobre estos salarios lo encontramos en CArretero Zamora, Cortes, Monarquía, ciudades, pp. 342 y ss.

97 Tabla realizada en base a datos extraídos de la documentación publicada por Olivera SERRANO, Las Cortes de Castilla y León.

${ }^{98}$ En alguno de los años que aquí presentamos fue realizada más de una concesión por parte de las Cortes., por lo que éstas han sido presentadas por separado. 
De esta forma, unos recursos extraordinarios, como lo fueron el pedido y las monedas, pudieron ser recaudados con la frecuencia de imposiciones ordinarias. No obstante, esto era sólo una solución temporal que se fue mostrando cada vez más ineficaz con el paso del tiempo. Cuando el sistema de recaudación de estos ingresos empezó a deteriorarse seriamente a mediados de siglo, toda la maquinaria fiscal del Estado empezó a tambalearse. Y es que los servicios de Cortes se habían convertido en el complemento indispensable de los recursos ordinarios de la Corona.

\section{CONCLUSIONES}

Al comienzo del presente artículo señalábamos la visión, un tanto estática, que se ha mostrado usualmente del pedido regio. La realidad, tal y como hemos pretendido demostrar, era bien distinta. A lo largo los años centrales del siglo XV diversos aspectos del proceso de concesión, recaudación y del gasto de este subsidio experimentaron transformaciones de suma importancia, que no pueden dejar de ser tenidas en cuenta. Uno de los principales motores que impulsaron las mutaciones que experimentó esta ayuda fue la siempre compleja relación mantenida entre las Cortes y el monarca. En este sentido, la historia del pedido regio resulta una perspectiva privilegiada para comprender cual fue el verdadero papel de las Cortes en la historia de Castilla. Es indudable que esta institución era un organismo en clara decadencia ya desde principios del siglo XV, pero no dejó de mostrar cierta resistencia a su situación de postración y trató de alcanzar un protagonismo que le fue negado, una y otra vez, a lo largo de estos años.

El mayor retroceso que este organismo tuvo que experimentar en sus aspiraciones se produce, precisamente, en la década de los cincuenta del siglo XV. Es entonces cuando se hace patente que el gran paso que creían haber dado hacia su principal objetivo con las disposiciones emitidas en Olmedo en 1445 era solo una ilusión, ya que el rey no dudaba en atentar contra ellas. Los procuradores solo podían solicitar, una y otra vez, la confirmación de sus prerrogativas y esperar que éstas fueran respetadas lo máximo posible, aunque ello dependiera por entero de la venia del monarca. Cabe preguntarse si Juan II, de haber vivido un poco más y una vez asentada la situación política tras la ejecución de don Álvaro de Luna, habría mantenido esta ficción. El condestable de Castilla había sido uno de los principales artífices de lo ocurrido en Olmedo ${ }^{99} \mathrm{y}$, pese a su concepción de la autoridad monárquica y a que él mismo había participado en la limitación de éstas prerrogativas, parece que siempre tuvo en cierta consideración hacia las Cortes ${ }^{100}$. Desaparecido él de escena, parece que éstas perdían a uno de sus principales valedores en la defensa de sus derechos.

Lo cierto es que aunque la actitud que hubiese adoptado Juan II es una incógnita, si que conocemos lo que ocurrió a continuación. Enrique IV, una vez ascendido al trono, no dudó a la hora de acabar con esta normativa fijada en Olmedo y volver a controlar la designación de los agentes fiscales del servicio, quedando éstos bajo su control directo. Aunque no existe ni una sola mención a este asunto en la documenta-

99 Olivera Serrano, Las Cortes de Castilla y León, pp. 19 y ss.
100 Ibid. 
ción que ha llegado hasta nosotros de las Cortes de Córdoba de 1455, resulta evidente que la decisión se adoptó este año, ya que disponemos de los documentos de nombramiento de los recaudadores mayores del pedido por parte del monarca ${ }^{101}$. Para acallar cualquier posible protesta Enrique, siguiendo los pasos de su padre, aumentó la asignación que los procuradores percibían sobre el dinero recaudado en los servicios. Así se constituye una nueva figura, la de las "enmiendas de los recaudimientos" 102 , que venía a sumarse a unos salarios y unas ayudas de costas que, por sí solas, ya habían convertido la actividad del procurador en un negocio muy rentable ${ }^{103}$.

Pero aunque el control del rey sobre los servicios volvía a ser casi absoluto, poniendo fin a un tira y afloja que había extendido durante los diez últimos años, los importantes problemas que aquejaban al sistema de recaudación del ingreso extraordinario más importante de la Corona seguían agravándose y no podían ser ignorados. En las citadas Cortes de Córdoba de 1455 los representantes de las ciudades fueron especialmente insistentes acerca de la necesidad de tomar decisiones urgentes al respecto. Precisamente la ciudad de Sevilla aparece en el cuaderno de Cortes de este año como el territorio fiscal que más parece preocupar a los procuradores. Así, por ejemplo, vemos como los abusos relacionados con los exentos de la ciudad hispalense se convierten en un tema largamente tratado en las peticiones incluidas en este cuaderno ${ }^{104}$, junto al mal funcionamiento del sistema de repartimiento de las cantidades exigidas y el desigual repartimiento de la carga fiscal ${ }^{105}$. La gravedad de la situación se refleja claramente en los datos de descargo de 1455-1456, que ya mostramos en el cuadro 3 .

Sin embargo, y pese a lo preocupante que empezaba a ser la situación, lo cierto es que no se adoptó ninguna medida novedosa para hacer frente a esta situación. Enrique, que contaba con la tranquilidad financiera que le proporcionaba el hecho de contar con un amplio patrimonio personal ${ }^{106}$, decidió no acometer la necesaria remodelación del sistema de ingresos ordinarios de la Hacienda. Así mismo, tampoco se trató de reducir la enorme cantidad de situado a la que había de hacerse frente cada año para el pago de dádivas y mercedes ${ }^{107}$. De esta manera, los problemas aquí señalados continuaron creciendo al tiempo que los servicios eran utilizados, cada vez más, para hacer frente a gastos ordinarios. El nuevo monarca ni siquiera tuvo la deferencia de disimular tal hecho. Así, en el ayuntamiento celebrado en Valladolid en 1457-1458

\footnotetext{
${ }^{101}$ AGS, EMR, Leg. 5, ff. 218r-219v.

102 Olivera Serrano, Las Cortes de Castilla y León, p. 70.

${ }^{103}$ Así lo muestra el aumento de la asignación media pagada por el monarca a cada procurador CARRETERO Zamora, Cortes, Monarquía, ciudades, p. 345.

${ }^{104}$ Cortes, III, pp. 679 y ss.

${ }^{105}$ Cortes, III, pp. 689 y ss.

106 " [...] pero infundíales temor el poder del Rey, en tan inmensas riquezas asentado; pues primeramente, la cuantiosa herencia materna vino a engrosar las grandes rentas que percibió siendo Príncipe; después se apoderó del tesoro acumulado por don Álvaro, y que a la muerte de éste se apropió D. Juan II, y por último cobró en aquellos pocos días de reinado y en virtud de nuevos repartimientos de impuestos otras cantidades, así de las rentas del Maestrazgo de Santiago, que reservó en su persona, como de las del de Alcántara, con igual avaricia retenidas a la muerte de don Gutierre de Sotomayor, último Maestre." Palencia: Crónica de Enrique IV, p. 62. En torno a este asunto consúltese también SuÁrez Fernández, Enrique IV de Castilla, p. 131.

${ }^{107}$ Para una idea de la importancia de las mismas puede consultarse a SuÁrez Fernández, "Un libro de asientos"
} 
Enrique reconoció, sin ningún empacho, que la buena parte del dinero concedido en las Cortes de Córdoba de 1455 se había destinado a asuntos como el pago de los juros de Juan de Navarra y sus parientes ${ }^{108}$ o el pago de las mandas testamentarias de su padre $^{109}$. La situación se fue volviendo más crítica conforme los recursos personales de Enrique se fueron gastando y su débil carácter se fue haciendo más patente. La guerra civil castellana vino a dar la puntilla a un subsidio que se encontraba seriamente dañado desde, al menos, los comienzos del reinado de este monarca.

Los años finales del reinado de Enrique IV y los primeros del de los Reyes Católicos asistieron a numerosos intentos por solucionar los problemas de un ingreso que era incapaz de recaudar las sumas demandadas. Incluso, vemos como la reina Isabel llegó a devolver a los procuradores la capacidad de nombrar a los agentes fiscales encargados del pedido $o^{110}$, buscando desesperadamente que la mayor implicación de las ciudades en el proceso de recaudación ayudara a paliar los graves problemas que lo aquejaban. Pero todos estos intentos fueron en vano. Es por ello que Isabel y Fernando, conscientes de que ninguna de las medidas adoptadas podía ya hacer frente a un recurso lastrado, optaron por hacer desaparecer el pedido y las monedas y lo sustituyeron por los ingresos que habían de percibirse a través de la Santa Hermandad a partir de 1478, con la esperanza de lograr así la necesaria base económica para emprender el ambicioso programa político que tenían en mente ${ }^{111}$.

\section{BIBLIOGRAFÍA}

Cortes de los antiguos reinos de León y de Castilla, vol. III, Real Academia de la Historia, Madrid, 1866.

Crónica anónima de Enrique IV de Castilla. Edición de María Pilar Sánchez-Parra, Editorial la Torre, Madrid, 1991.

Aguado González, Francisco José, "Fuentes para el estudio de la geografía administrativa y la distribución de la población de la Corona de Castilla en la segunda mitad del siglo XV: las relaciones de pueblos para el cobro del pedido", Anuario de Estudios Medievales, $\mathrm{n}^{\circ}$ 16, (1986), pp. 465-480.

Arco y Garay, Ricardo del, Sepulcros de la Casa Real de Castilla, Concejo Superior de Investigaciones Científicas Jerónimo Zurita, Madrid, 1954.

Carretero Zamora, Juan Manuel, Cortes, Monarquía, ciudades. Las Cortes de Castilla a comienzos de época moderna (1476-1515), Siglo XXI, Madrid, 1988.

\footnotetext{
${ }^{108}$ AGS, EMR, Leg. 8, ff. 849r-861v.

109 SuÁrez Fernández, Enrique IV de Castilla, p. 193.

110 AGS, EMR, Leg. 19, f. 37r-v.

111 Para un estudio de la Hermandad desde una perspectiva fiscal véase LADERo QueSADA, La Hermandad de Castilla.
} 
CARretero Zamora, Juan Manuel, "Fiscalidad extraordinaria y deuda: el destino del servicio de las Cortes de Castilla (1535-1537), Espacio, tiempo, forma, Serie IV, $\mathrm{H}^{\mathrm{a}}$ Moderna, t. 8, (1995), pp. 11-47.

Collantes de Terán Sánchez, Antonio, Sevilla en la Baja Edad Media: la ciudad y sus hombres, Ayuntamiento de Sevilla, Sevilla, 1977.

Collantes de Terán SÁnchez, Antonio, "La élite financiera en la Sevilla bajomedieval: los Mayordomos del Concejo", Revista d'historia medieval, $\mathrm{n}^{\mathrm{o}}$ 11, (2000), pp. $13-40$.

COOPER, Edward, "La Iglesia y los comuneros: una interpretación anti-antiseñorial", en Martínez Gil, Fernando (coord.), En torno a las Comunidades de Castilla. Actas del Congreso Internacional "Poder, conflicto y revuelta en la España de Carlos I", Universidad de Castilla y la Mancha, Cuenca, 2002, pp. 279-308.

Díaz de Durana Ortíz de Urbina, José Ramón y García Fernández, Ernesto, Demografia y sociedad: la población de Logroño a mediados del siglo $X V$. Instituto de Estudios Riojanos, Logroño, 1991.

GonzÁlez ArCe, José Damián, "Los precedentes de la fiscalidad extraordinaria de la Monarquía hispana: los pedidos reales en la Castilla al sur del Tajo (s. XIV y XV)", en Collantes de Terán SÁnchez, Antonio (ed.), Fuentes para el estudio del negocio fiscal y financiero en los reinos hispánicos (siglos XIV-XVII). Instituto de Estudios Fiscales, Madrid, 2010, pp. 11-40.

LADERo Quesada, Miguel Ángel, La Hermandad de Castilla: cuentas y memoriales (1480-1498). Real Academia de la Historia, Madrid, 2005.

Ladero Quesada, Miguel Ángel, La Hacienda Real de Castilla (1369-1504), Real Academia de la Historia, Madrid, 2009.

Ladero Quesada, Miguel Ángel, Fiscalidad y poder real en Castilla (1252-1369), Real Academia de la Historia, Madrid, 2011.

Olivera Serrano, César, Las Cortes de Castilla y León y la crisis del reino. El registro de Cortes. Cortes de Castilla y León, Burgos, 1986.

Olivera Serrano, César, "Pedidos y monedas en Valladolid y su infantado a mediados del siglo XV", en Valladolid: historia de una ciudad, vol. 1, Universidad de Valladolid, Valladolid, 1999, pp. 315-326.

Olivera Serrano, César, "El pedido de 1455 en el reino de Galicia", Cuaderno de estudios gallegos, Tomo LI, fascículo 117, (2004), pp. 363-374.

Ortego Rico, Pablo, "Justificaciones doctrinales de la soberanía fiscal regia en la Baja Edad Media castellana”, En la España Medieval, n³2, (2009), pp. 113-137.

Palencia, Alonso de: Crónica de Enrique IV, vol. I, Edición de Antonio Paz y Meliá, Atlas, Madrid, 1973.

Peláez Rovira, Antonio, El emirato nazarí de Granada en el siglo XV: dinámica politica y fundamentos sociales de un estado andalusí. Universidad de Granada, Granada, 2006.

Rodríguez Sarria, Julieta, “¿Cobrar para el rey? Procedimientos y agentes de la recaudación en la Sevilla del siglo XV”, en Galán Sánchez, Ángel y García Fer- 
nández, Ernesto (coord.), En busca de Zaqueo: los recaudadores de impuestos en las épocas medieval y moderna, Instituto de Estudios Fiscales, Madrid, 2012, pp. 79-98.

Rodríguez SARRIA, Julieta, "Fisco, poder y distinción social en Sevilla y su tierra en el siglo XV: una propuesta de trabajo", en Vitores Casado, Imanol; Añibarro Rodríguez, Javier; Y Carvajal De La Vega, David, Poder, fisco y mercado: la ciudad y sus redes en la Baja Edad Media (en prensa)

Romero Martínez, Adelina, Fisco y recaudación: impuestos directos y sistemas de cobro en la Castilla Medieval, Universidad de Granada, Granada, 1999.

Romero Romero, Francisco José, "El Concejo como instrumento de la fiscalidad regia en la Castilla del siglo XV. Sevilla y los pedidos de Cortes (1406-1474)" en López De Coca Castañer, José Enrique Y Galán Sánchez, Ángel (eds.), Actas del VI Coloquio Internacional de Historia Medieval de Andalucia. Universidad de Málaga, Málaga, 1991, pp. 161-166.

Romero Romero, Francisco José, Sevilla y los pedidos de Cortes, Ayuntamiento de Sevilla, Sevilla, 1997.

Round, Nicholas, The greatest man uncrowned. A history of the fall of don Alvaro de Luna, Tamesis Books, London, 1986.

Rubio Martínez, Amparo, "Los ingresos extraordinarios en el reino de Galicia en el siglo XV", Cuaderno de estudios gallegos, Tomo LVII, nº123, (2010), pp. 229271.

SÁnchez Albornoz, Claudio, "Notas para el estudio del Petitum", en Homenaje a don Ramón Carande, vol. II, Sociedad de Estudios y Publicaciones, Madrid, (1963), pp. 383-418.

SÁnchez Saus, Rafael, Caballería y linaje en la Sevilla medieval: estudio genealógico y social. Diputación provincial de Sevilla y Universidad de Cádiz, Sevilla, 1989.

SuÁREZ FernÁndez, Luis, "Un libro de asientos de Juan II", Hispania: revista española de Historia, ${ }^{\circ} 68$, (1957), pp. 322-368.

SuÁREZ FernáNDEZ, Luis, Enrique IV de Castilla: la difamación como arma política. Ariel, Barcelona, 2001.

SuÁrez Fernández, Luis, Nobleza y Monarquía. Entendimiento y rivalidad. El proceso de construcción de la Corona española. La Esfera de los libros, Madrid, 2003.

Triano Milán, José Manuel, "El Arzobispado de Sevilla y el Obispado de Cádiz. Imagen de un gran partido fiscal en la recaudación del pedido regio", Historia, instituciones y documentos, $\mathrm{n}^{\mathrm{o}}$ 40, (2013), pp. 361-395.

VALdeÓn BaruQue, Julio, "Las Cortes de Castilla y las luchas políticas del siglo XV (1419-1430)", Anuario de Estudios Medievales, n³, (1966), pp. 293-326.

Vincens Vives, Jaime, Juan II de Aragón (1398-1479). Monarquía y revolución en la España del siglo XV, Edición de de Paul Freedman y Josep M. Muñoz i Lloret, Urgoiti editores, Pamplona, 2003. 